\title{
PERAN PEREMPUAN SINGLE MOTHER DALAM KELUARGA MISKIN DI JORONG BALAI MANSIRO NAGARI GUGUAK VIII KOTO
}

\author{
Jasmienti \\ IAIN Bukittinggi e-mail jasmienti01@gmail.com \\ Nofrianti Putri Utami \\ LAIN Bukittinggi e-mail nofriantiutami27@gmail.com
}

Diterima: 16 Mei 2019

Direvisi : 7 November 2019

Diterbitkan : 25 Desember 2019

\begin{abstract}
This study aims to determine the role of single mother in poor families. This research used qualitative research. The method of collecting data was by interviewing several informants and observing some single mother. An interesting phenomenon in poor families were in sustaining life with a decent standard of living, firstly on saving the expenditure side, postpone the expenses related to transportation. Second, the income of households, poor households forced them to optimize their income through the mobilization of their economic resources. This effort is carried out to be able to maintain a level of welfare or a decent life. However, not all of these efforts are able to maintain at a decent level of life.
\end{abstract}

Keywords: Single Mother. Poor Family, women in the family

\begin{abstract}
Abstrak
Artikel ini bertujuan untuk mengetahui peranan perempuan single mother dalam keluarga miskin. Penelitian ini menggunakan penelitian kualitatif. Metode pengambilan data dengan cara interview kepada beberapa informan dan observasi kepada beberapa perempuan single mother. Fenomena yang menarik pada keluarga miskin dalam mempertahankan hidup dengan tingkat kehidupan yang layak, yaitu pertama pada sisi pengeluaran melakukan penghematan pada pengeluaran yang dirasakan dapat ditunda, pengeluaran-pengeluaran yang berkaitan dengan transportasi sedapat mungkin dihindari atau dikurangi. Kedua, pada sisi pendapatan rumah tangga pada rumah tangga miskin telah memaksa mereka untuk melakukan pengoptimalan pendapatan melalui pengerahan sumber daya ekonomi yang dimiliki. Upaya ini dilakukan dalam upaya untuk tetap dapat mempertahankan tingkat kesejahteraan atau kehidupan yang layak. Namun demikan upaya ini tidak semuanya mampu untuk dapat mempertahankan pada tingkat kehidupan yang layak.
\end{abstract}

Kata Kunci: Single Mother, Keluarga Miskin, Perempuan dalam Keluarga

\section{Latar Belakang}

Kemiskinan merupakan masalah yang selalu dihadapi oleh manusia. Masalah kemiskinan sudah sejak lama ada bahkan kemiskinan tersebut sama tuanya dengan usia kemanusiaan itu sendiri dan akibatnya dapat melibatkan berbagaai segi kehidupan manusia. Kemiskinan merupakan masalah sosial yang sudah bersifat global dan kemiskinan tersebut sudah lama menjadi pusat perhatian dunia dan masalah kemiskinan ada di semua negara walaupun dampak dari kemiskinan tersebut berbeda-beda. Banyak yang mendefenisikan tentang kemiskinan dan sebagian besar mendefenisikan kamiskinan tersebut dengan aspek ekonomi.

Isu kemiskinan erat kaitannya dengan sebuah keluarga. Keluarga memiliki kewajiban untuk memenuhi kebutuhan-kebutuhan untuk anak-anaknya yang meliputi kebutuhan 
spiritual, psikologis, sandang, pangan dan papannya. Adapun tujuan untuk membentuk keluarga adalah untuk mewujudkan kesejahteraan anggota keluarganya. Dalam konsep keluarga berlaku pembagian tugas peran suami istri. Salah satu tugas dalam keluarga adalah menjadi orang tua. Segala urusan rumah tangga dan pengasuhan anak menjadi tanggung jawab istri, sedangkan suami bertugas untuk mencari nafkah agar kebutuhan ekonomi dalam keluarga terpenuhi. Tapi berbeda dengan perempuan yang hanya menghidupi keluarganya seorang diri, yang biasa disebut dengan single mother. ${ }^{1}$

Single mother adalah perempuan yang menjadi orang tua tunggal bagi anak-anaknya sebagai akibat perceraian dan kematian. Tugas perempuan menjadi lebih berat jika menjadi perempuan yang sudah menikah pastilah tidak pernah berharap menjadi seorang single mother, keluarga lengkap tetap menjadi idaman setiap perempuan, namun adakalanya nasibA. berkehendak lain ${ }^{2}$.Kenyataannya kondisi ideal $\mathbf{B}$. tersebut tidak dapat dipertahankan atau diwujudkan. Banyak dari perempuan yang memilih bahkan terpaksa menjadi single mother.

Tidak banyak single mother yang bahagia dengan status tersebut, apalagi jika keadaan ekonomi keluarganya tidak baik setelah ditinggal oleh suaminya. Banyak dari single mother yang harus mengurus kelurganya dengan begbagai keterbatasan termasuk dalam keterbatasan ekonomi. Mereka harus berjuang sendiri untuk memenuhi kehidupan keluarganya, mulai dari mencari nafkah sampai kepada mendidik anak-anaknya, dan itu mereka lakukan seorang diri.

\section{Metode Penelitian}

1 Nofrianti Putri Utami dan Silfia Hanani. 2018. Kebertahanan Perempuan Simalanggang Menjadi Single Mother.

2 Sarnita Maripadang. 2013. Peran Single Parent Dalam Menjalankan Fungsi Keluarga. Skripsi: Universitas Hasanuddin hlm 2 orang tua tunggal (single mother). Setiap Jurnal Turast Vol 6 No 1 hlm 25

Fenomena kehidupan rumah tangga miskin dengan keterlibatan para istri/ibu rumah tangga dalam kegiatan ekonomi, sebetulnya terjadi di hampir seluruh wilayah, namun sebagai sampelnya, maka pada penelitian ini, lokasi yang diambil adalah Jorong Balai Mansiro Nagari Guguak VIII Koto. Jenis data pada penelitian ini adalah data primer yang berupa data perempuan single mother di Jorong Balai Mansiro Nagari Guguak VIII Koto. Populasi dalam penelitian ini adalah perempuan single mother di Jorong Balai Mansiro Nagari Guguak VIII Koto. Sampel diambil dengan menggunakan metode purposive random sampling. Teknik pengumpulan data dilakukan melalui wawancara mendalam, wawancara ini dilakukan untuk memperdalam informasi dan melakukan observasi langsung, dua metode ini (wawancara secara mendalam dan observasi langsung) sejalan dengan teknik observasi pasif.

\section{. Subjek Penelitian}

Jumlah penduduk di Jorong Balai Mansiro Nagari Guguak VIII Koto adalah 242 jiwa, dimana 101 jiwa berjenis kelamin laki-laki dan 141 jiwa berjenis kelamin perempuan.

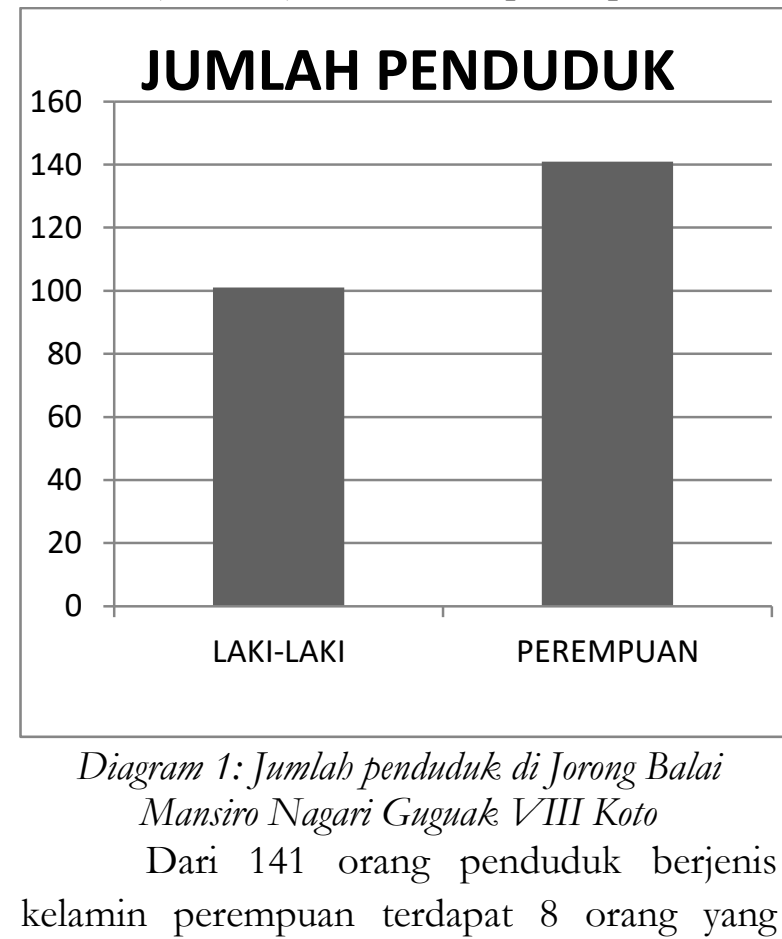


menyandang status sebagai single mother. Dari 8 orang single mother yang ada di jorong tersebut 4 diantaranya berpofesi sebagai petani dan empat lainnya adalah ibu rumah tangga.

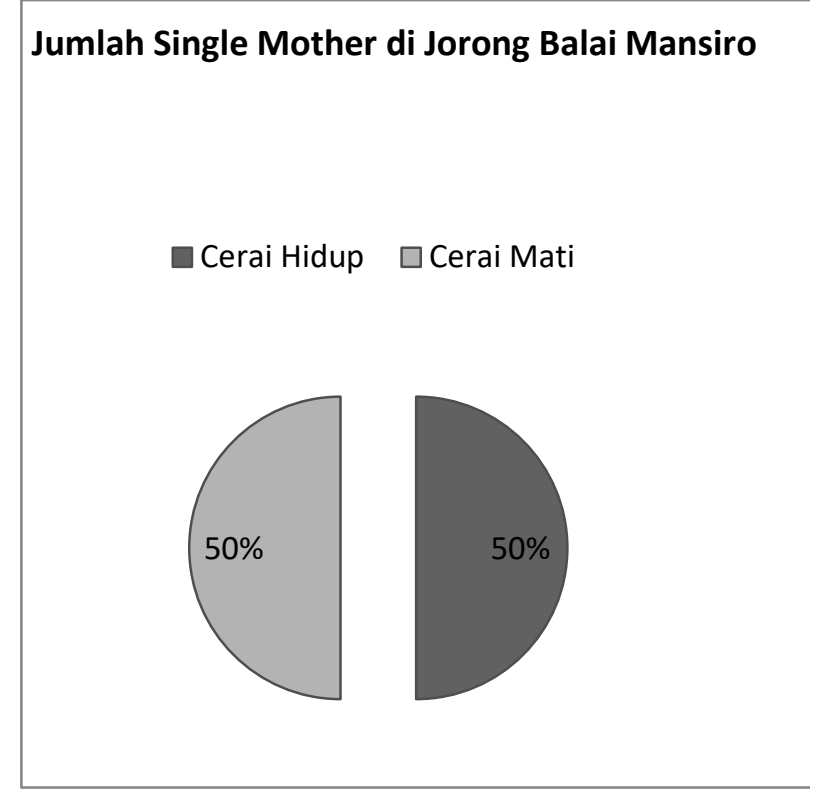

Diagram 2 : Jumlah single mother di Jorong Balai Mansiro Nagari Guguak VIII Koto

Dari diagram di atas terdapat 4 orang single mother yang cerai hidup dan 4 orang single mother yang cerai mati, jadi persentase single mother di Jorong Balai Mansiro Nagari Guguak VIII Koto adalah 50\% untuk cerai mati dan $50 \%$ untuk cerai hidup.

\section{Alasan Perempuan Menjadi Single Mother}

Single mother adalah perempuan yang sudah tidak memiliki suami lagi. Ada dua alasan yang melatarbelakangi perempuan di jorong Balai Mansiro menjadi single mother, diantaranya:

1. Perceraian

Di dalam sebuah keluarga, perkawinanan melibatkan dua individu lakilaki dan perempuan dengan kepribadian masing-masing dan latar belakang yang berbeda yang berusaha untuk hidup bersama. Alasan terjadinya sebuah perceraian adalah harapan-harapan dan keinginan-keinginan yang berlebihan yang diharapkan ada kepada masing-masing pasangan. Harapan ini dapat berupa status sosial dan hubungan-hubungan bersifat seksual, popularitas, jaminan kesehatan, jaminan pekerjaan yang tepat sebagai suami istri. $^{3}$

Di Jorong Balai Mansiro ada 4 orang perempuan yang menjadi single mother karena perceraian. Dari ke 4 perempuan tersebut bercerai karena tidak ada kecocokan antara suami dan istri, karena sering terjadinya perselisihan antara kedua belah pihak, maka mereka memutuskan untuk berisah/ barcerai saja.

Perceraian bukan suatu peristiwa tunggal, namun perceraian merupakan suatu proses, rangkaian yang potensial membawa pengalaman yang penuh stress yang mulai sebelum perpisahan fisik dan berlanjut setelahnya. Perceraian terjadi karena kesepakan kedua belah pihak antara suami dan istri untuk tidak hidup bersama lagi. Perceraian cenderung mengurangi kesejahteraan dalam keluarga, terutama bagi pihak pasangan yang tidak menginginkan perceraian tersebut atau tidak ingin menikah kembali. Alasan-alasan tersebut dapat mencakup gangguan hubungan orang tua dan anak, keributan dengan mantan pasangan, kesulitan ekonomi, kehilangan dukungan emosional, dan harus pindah dari rumah keluarga.

Dalam konstruksi masyarakat, perempuan cukup umur yang masih lajang, janda cerai dan perempuan yang mempunyai anak tanpa suami, memiliki status yang lebih rendah di dalam masyarakat. Terdapat beberapa strategi sosial yang dilakukan single mother dalam menjalankan perannya sebagai orangtua tunggal di dalam kehidupan bermasyarakat.

${ }^{3}$ Nur Fadillah. 2015. Peran Ibu 'Single Parent" Dalam Menumbubkan Kemandirian Anak Di Desa Bojong Timur Magelang. Skripsi. Fakultas Ilmu Sosial Universitas Negeri Semarang hlm 12 
Pertama, tinggal di rumah orangtua. Sebagian besar single mother yang telah bercerai dan berpisah dari suaminya memilih untuk kembali tinggal bersama orangtua. Hal ini dilakukan single mother secara tidak langsung untuk menghidari gunjingan dan tekanan sosial dari masyarakat tentang statusnya sebagai janda cerai yang telah ditinggalkan oleh suaminya. Sebagian perempuan yang telah berpisah dengan suami akan memilih untuk kembali tinggal bersama orangtuanya karena selain merasa nyaman, orangtua juga berperan dalam pemberian motivasi dan perlindungan agar tetap semangat dalam menjalani hidup meskipun tanpa suami. Orangtua memberikan perlindungan terhadap berbagai macam bentuk tekanan sosial di masyarakat, dengan tinggal bersama orangtua masyarakat lebih menghargai dan menghormati mereka meskipun beliau adalah seorang single mother dengan status janda cerai. ${ }^{4}$

Kedua, yang diberikan orangtua single mother ketika single mother menanggung beban hidup kedua orangtuanya. Bagi single mother yang kembali tinggal bersama orangtuanya, mereka akan menanggung baban hidup orangtuanya terlebih jika kedua orangtua single mother sudah tidak mampu bekerja lagi, maka segala beban ekonomi dan kebutuhan sehari-hari akan ditanggung oleh single mother. Dengan tinggal bersama orangtua bukan berarti beban mereka berkurang dan juga mendapatkan bantuan dari ibunya dalam hal pengasuhan anaknya yang masih berumur. Selain terlibat dalam hal pengasuhan anak ketika single mother bekerja, mereka yang tinggal bersama orangtua juga mendapatkan motivasi dan semangat untuk terus berjuang menafkahi anaknya, karena

${ }^{4}$ Afina Septi Rahayu, 2017. Kebidupan Sosial Ekonomi Single Mother dalam Ranah Domestik dan Publik. Jurnal Analisa Sosiologi Vol 6 No 1 hlm 92 anak adalah investasi tak ternilai bagi single mother. Dengan pemberian dorongan dan semangat tersebut, single mother bisa bangkit dari keterpurukan pasca bercerai dan akan kembali bersemangat melanjutkan hidup demi anaknya.

Ketiga, single mother lebih memilih untuk menafkahi dan membesarkan anaknya secara mandiri tanpa bantuan dari mantan suami. Ketika perceraian terjadi, dalam pengadilan akan diputuskan berapa nafkah yang yang harus diberikan suami untuk anaknya. Besar kecilnya jumlah nafkah tersebut disepakati antara kedua belah pihak, istri dan suami. Masalah timbul apabila mantan suami ingkar dari tanggungjawab dan tidak memberikan nafkah untuk anaknya. Oleh karena itu single mother lebih memilih untuk mengurus dan membesarkan anaknya sendiri tanpa ada campur tangan dari mantan suaminya. Bentuk eksistensi single mother mulai ditunjukkan dalam hal mengasuh dan membesarkan anaknya, dengan demikian mereka akan dilihat sebagai sosok yang mandiri dan bisa bertahan hidup meskipun tanpa ada sosok lelaki sebagai suami di sampingnya.

2. Kematian

Seorang perempuan yang telah menyandang status sebagai istri bisa menjadi single mother ketika suaminya meninggal. Baik itu meninggal karena kecelakan ataupun meninggal karena suatu penyakit yang diderita suaminya. Kematian yang menimpa sang suami membuat seorang istri menjadi orang tua tunggal untuk anak-anaknya. Sang ibupun harus menjadi lebih kuat lagi karena harus menjadi ayah serta ibu bagi anak-anaknya setelah ditinggal mati oleh suaminya. Disini tidak ada pihak yang menginginkan perpisahan ini, ini terjadi karena takdir, dan sang istri pun harus menerima takdir 
tersebut dengan menjadi orang tunggal untuk anak-anaknya.

Empat dari delapan single mother yang ada di Jorong Balai Mansiro tersebut menyandang status single mother karena kematian suami, ada yang meninggal karena sakit dan ada juga yang meninggal karena kecelakaan, oleh karena itu mereka harus membesarkan dan menanggung biaya hidup seorang diri.

Setiap perempuan tidak pernah berharap menjadi orang tua tunggal bagi anak-anaknya, namun adakalanya nasib berkehendak lain. Pada kenyataannya kondisi ideal tersebut tidak selamanya bisa dipertahankan atau diwujudkan karena dua faktor di atas tersebut. Mereka harus dengan terpaksa menerima keadaannya sebagai seorang perempuan single mother. ${ }^{5}$ Apalagi dikalangan keluarga miskin, kemiskinan adalh masalah yang tidak saja melibatkan factor ekonomi tapi juga factor sosial dan budaya dimana kebutuhan pokok adalah prioritas utama.

\section{Peran Perempuan Single Mother di Jorong Balai Mansiro}

\section{Peran Perempuan Secara Umum}

Dalam kehidupan bermasyarakat secara umum, perempuan juga memiliki peranan, diantaranya:

1. Peran Domestik

Rumah tangga (domestik) peranan wanita sangatlah penting. Peran seorang wanita (ibu) dapat dikategorikan dalam dua bagian: a) Peran sebagai istri, yaitu seorang istri dituntut untuk mengetahui jalan pikiran suami yaitu dapat menjadi pendengar yang baik, dapat orang yang bijak dalam mempertimbangkan masalah, melayani kebutuhan lahir suami seperti melayani aktivitas didapur, sumur dan

5 Cahyani, Kurnia Dwi. 2016. Masalah Dan Kebutuban Orang Tua Tunggal Sebagai Kepala Keluarga. EJournal Bimbingan Konseling Edisi 8 tahun ke-5 hlm 157 kasur. b) Peran sebagai ibu, yaitu mengurus dan mendidik anak-anaknya.

Di Jorong Balai Mansiro para single mother hanya menjalankan peranannya sebagai ibu yaitu mengurus dan mendidik anaknya, disini seorang ibu harus mencari nafkah seorang diri untuk mencukupi kebutuhan anak-anaknya, baik untuk kehidupan sehari-hari maupu untuk pendidikan anak-anaknya.

2. Peran Publik

Pergeseran peran perempuan dari peran domestik kepublik merupakan tanda penting dari perkembangan realitas sosial, ekonomi, dan politik wanita. Kesadaran wanita tentu semakin meningkat terhadap peran non-domestik, terlepas didasari oleh kepentingan apa dan siapa. Namun keterlibatan itu bukan berarti oleh laki-laki dan oleh berbagai kepentingan lain, seperti Negara dan kapitalisme. Wanita telah menjadi faktor penting dalam ekonomi rumah tangga. Terutama pada saat laki-laki kehilangan kesempatan terlibat akibat segmentasi pasar tenaga kerja. Wanita akhirnya melihat dunia kerja semacam dunia baru yang masih rawan dan tidak aman bagi mereka. Belum lagi kendala yang dihadapi dalam keluarga, suatu persoalan yang muncul akibat keterlibatan mereka di luar rumah. ${ }^{6}$ Di Jorong Balai Mansiro peran perempuan single mother dalam keluarga sangatlah penting, mereka harus keluar dari zona nyamnya, mereka harus turun tangan langsung dan berusaha mencari pekerjaan di luar rumah. Sebagian dari single mother yang ada di Jorong Balai Mansiro bekerja sebagai petani menggantikan posisi mantan suami atau almarhum suaminya.

Dalam keluarga perlu ada kepala keluarga sebagai tokoh penting yang

6 Nilatu Musyiroh, 2018. Peranan Perempuan Single Parent Dalam Peningkatan Kesejabteraan Keluarga. Skripsi Universitas Islam Negeri Sumatera Utara. Hlm 9 
mengemudikan perjalanan hidup keluarga yang diasuh dan dibinanya, karena keluarga sendiri terdiri dari beberapa orang, maka terjadi interaksi antar pribadi, dan itu berpengaruh terhadap keadaan harmonis dan tidak harmonisnya pada salah seorang anggota keluarga, yang selanjutnya berpengaruh pula terhadap pribadi-pribadi lain dalam keluarga. Namun keadaan ini menjadi berbeda ketika seorang perempuan harus menyandang status sebagai orang tua tunggal bagi anak-anaknya.

Seorang ibu tunggal boleh dikatakan sebagai single mother apabila wanita itu telah kematian suami dan terpaksa meneruskan tugas membesarkan anak-anak atau seorang wanita yang telah bercerai dengan suaminya dan diberi hak penjagaan atas anak-anaknya ataupun seorang wanita yang digantung (statusnya tidak jelas) karena tidak diberi nafkah oleh suami untuk mememnuhi hidupnya dan anak- anaknya ataupun seorang wanita dalam proses perceraian yang mungkin akan mengambil masa yang panjang dan anakanaknya masih dibawah penjagaannya pada waktu ini. ${ }^{7}$

Perempuan berperan penting dalam pembentukan kehidupan keluarga yang kokoh sehingga tidak terkena pengaruh negatif dari perubahan serta pencapaian suatu keadaan yang sehat, sejahtera dan bahagia, sehingga mendukung terhadap penciptaan masyarakat yang sejahtera, baik lahir maupun batin. Kemampuan dan potensi yang memadai dari perempuan sebagai ibu rumah tangga merupakan aspek terpenting dalam menentukan keberhasilan (penunjang utama strategi suksesnya) suatu rumah tangga (terutama masa depan anak/anak generasi penerus). Oleh karena itu, diperlukan inovasi dan adopsi yang berkaitan dengan strategi peningkatan kemampuan dan potensi kaum

${ }^{7}$ Nur Fadillah. 2015. Peran Ibu 'Single Parent" Dalam Menumbubkan Kemandirian Anak Di Desa Bojong Timur Magelang. Skripsi. Fakultas Ilmu Sosial Universitas Negeri Semarang hlm 10 perempuan, sehingga perempuan dapat berperan optimal di sektor domestik secara professional. $^{8}$

Bagi single mother yang disebabkan oleh perceraian, mereka tidak mendapatkan dukungan dan nafkah dari mantan suaminya untuk memenuhi kebutuhan anak-anaknya, karena itu perempuan lah yang harus mencukupi dan mencari nafkah untuk memenuhi kebutuhannya dan kebutuhan anak-anaknya sampai sang anak dewasa. Sehingga single motherlah yang harus matimatian banting tulang untuk membesarkan anak-anaknya sendiri tanpa bantuan dari mantan suaminya. ${ }^{9}$ Di Jorong Balai Mansiro para perempuan sngle mother yang berpisah karena perceraian pada umumnya para mantan suami lepas tanggung jawab terhadap keutuhan anak-anaknya, sehingga wanita lah yang harus menutupi kebutuhan untuk anakanaknya, baik untuk kebutuhan sehari-hari anak maupun kebutuhan pendidikan anakanaknya. Terkadang para single mother harus bekerja paruh waktu, seperti siang hari bertani dan malam hari membungkus kerupuk untuk menambah pendapatannya.

Seorang single mother harus mengasuh anak-anaknya seorang diri karena kehilangan suami akibat perceraian atau meninggal dunia. Single mother dituntut untuk meluangkan waktunya dan membagi waktunya untuk memberi kasih sayang dan mencari nafkah untuk keluarga dan anak-anaknya. Perempuan single mother dituntut untuk bisa hidup mandiri dan melanjutkan kehidupannya tanpa seorang suami. Dalam kasus perceraian meskipun sang mantan suami masih memberikan uang nafkah untuk anak-anaknya, tapi ia tidak lagi memberikan uang dalam keadaan cukup untuk memenuhi kebutuhannya sehari-hari.

${ }^{8}$ Eva Fitria. 2019. Peran Aktif Wanita Dalam Peningkatan Pendapatan Rumah Tangga Miskin. Jurnal Ecobisma Vol 6 No 2 hlm 55

${ }^{9}$ Hanani, Silfia. 2018. Woman's Newspapers As Minangkabau Feminist Movement Againts Marginalization In Indonesia. Jurnal GJAT. Vol 8 No 2 hlm 78 
Terlebih sang mantan suami memilih untuk menikah lagi dan akan membiayai kehidupannya dengan istri barunya. Para single mother harus pandai-pandai dalam membagi waktunya dalam keluarga, ia dituntut untuk mengerjakan seluruh pekerjaan rumah dan harus berusaha mencukupi semua kebutuhan keluarga dan anak-anaknya.

Single mother yang ada di Jorong Balai Mansiro disebabkan karena perceraian dan kematian, empat diantaranya berpisah karena bercerai, karena dalam rumah tangga tersebut sudahtidak ada kecocokan lagi dan tidak ditemukan jalan keluar untuk berdamai dan diputuskanlah untuk berpisah/ bercerai. Empat yang lainnya menyandang status sinle mother karena kematian suami yang diakibatkan suami tersebut kecelakaan dan terserang penyakit, sehingga mereka harus siap dengan status single mothernya.

Status single mother menjadikan perempuan sebagai kepala kelurga, dimana perempuan memiliki peran ganda bagi ibu yaitu sebagai orang tua tunggal untuk mengurus anak-anaknya dan ia juga dituntut untuk bekerja guna mencari nafkah untuk memenuhi kebutuhan keluarganya. Menjadi single mother dalam sebuah keluarga tidaklah mudah, karena seorang ibu harus memainkan peran ganda dalam keluarganya yaitu menjadi ibu untuk anak-anaknya dan menjadi ayah untuk mencari nafkah memenuhi kebutuhan keluarga dan anak-anaknya.

Bagi seorang single mother yang ditinggal mati oleh suaminya ia akan merasa lebih kesulitan lagi, karena ia tidak bisa bergantung dan mengadu pada suaminya lagi, berbeda dengan seorang single mother yang disebabkan oleh perceraian, ia masih bisa meminta bantuan untuk memenuhi kebutuhan anakanaknya. Kematian pasangan jelas sangat berpengaruh bagi diri seorang perempuan, pasangan yang ditinggal terpaksa melakukan segala sesuatu pekerjaan keluarga dengan sendirinya tanpa bantuan dari sang suami lagi.
Seorang single mother harus berfikir sendiri bagaimana menghidupi keluarga dan anakanaknya tanpa harus merepotkan keluarga yang lain. Seorang single mother juga harus bisa mendidik anak-anaknya seorang diri. Single mother harus bertanggung jawab dalam keluarganya baik dalam penyedia keuangan, pemenuhan kebutuhan rumah tangga dan dalam mendidik anak-anaknya. Di Jorong Balai Mansiro single mother perempuan yang ditinggal karena sang suami meninggal dunia lebih kesusahan lagi, disamping harus memikirkan kehidupan keluarganya seorang diri ditambah lagi kondisi psikologis istri terganggu karena harus menerima kenyataan bahwa sang suami tidak bias lagi mendampingi hidupnya.

Keberhasilan seorang single mother dalam mendidik dan menafkahi anak-anaknya tergantung pada bagaimana ia bisa membagi waktu antara mencari nafkah dan mendidik anak-anaknya serta bagaimana ia bisa menyesuaikan diri dengan masyarakat sekitarnya dan bagaimana seorang single mother bertindak dan bersikap agar tidak di cemooh oleh masyarakat karena statusnya sebagai seorang single mother.

Perempuan single mother memiliki gambaran tentang makna hidup antara lain adalah bisa menjadi individu yang menghargai hidup, bisa menghadapi permasalahan dengan bijak, bisa lebih sabar dalam menghadapi permasalahan dan menjadi individu yang lebih baik. Single mother dituntut harus kuat dalam menjalani kehidupan tanpa sosok seorang suami disampingnya. Ia harus menjadi kuat dihadapan anak-anaknya agar mereka tidak merasa begitu kehilangan sosok ayah di dalam hidupnya.

Menurut teori struktural fungsional masyarakat merupakan suatu sistem sosial yang terdiri atas bagian-bagian atau elemen yang saling berkaitan dan saling menyatu dalam keseimbangan. Perubahan yang terjadi pada satu bagian akan membawa perubahan pula 
terhadap bagian yang lain. Asumsi dasarnya adalah bahwa setiap struktur dalam sistem sosial, fungsional terhadap yang lain. Sebaliknya kalau tidak fungsional maka struktur itu tidak akan ada atau akan hilang dengan sendirinya. ${ }^{10}$

Begitu pula dengan kajian Talcott Parsons dalam teori struktural fungsional ia melihat bahwa suatu masyarakat sebagai suatu sistem yang terdiri dari sub sistem yang saling berhubungan antara satu dengan yang lainnya. Dengan teori ini sebuah keluarga dianggap memiliki bagian yang terdiri dari adanya seorang ayah, seorang ibu, adanya anak-anak dan anggota keluarga lainnya. Setiap anggota disini dianggap sub sistemnya, yang tiap anggotanya memiliki fungsi masing- masing. Fungsi tersebut membawa konsekuensi tertentu bagi anggota keluarga dan bagi keluarga secara keseluruhan. Dalam hal ini dengan ketiadaan figur seorang ayah maka peranannya pun akan digantikan oleh seorang ibu, dengan begitu tentu saja akan merubah fungsi-fungsi yang ada di dalam keluarga tersebut, dan akan membawa konsekuensi bagi para anggota yang ada didalamnya. ${ }^{11}$

Telah menjadi tradisi sebagian besar masyarakat, bahwa keperluan harian rumah tangga seperti mencuci, membersihkan rumah, memasak, merawat anak, dan berbagai kesibukan lain di rumah adalah tanggung jawab seorang istri/ibu rumah tangga. Kebiasaan yang bahkan telah membudaya bagi sebagian besar masyarakat ini mengakibatkan seorang ibu rumah tangga yang single mother memiliki beban kerja yang tidak sedikit di dalam rumahnya. Berbagai kesibukan disertai dengan beban kerja yang tidak sedikit ini, terasa semakin bertambah berat jika sang ibu rumah tangga single mother harus terjun ke

\footnotetext{
${ }^{10}$ James M Henslin. 2007. Sosiologi dengan Pendekatan Membumi. Jakarta: PT Gelora Aksara Pratama hlm 118

11 George Ritzer. 2014. Teori Sosiologi Modern. Jakarta: Pranadamedia Group
}

lapangan pekerjaan mencari nafkah untuk memenuhi kebutuhan keluarganya. Mereka harus menjalani dua fungsi sekaligus sebagai ibu rumah tangga yang harus menyiapkan segala sesuatu keperluan anak, dan fungsi sebagai pencari nafkah bagi keluarganya. Hasil penelitian ini menggambarkan beratnya beban kerja seorang ibu rumah tangga single mother miskin apabila harus bekerja mencari nafkah untuk keluarga dan anaknya.

Peranan wanita dalam rumah tangga di Jorong Balai Mansiro dilihat dalam tiga hal, yaitu:

1. Peranan wanita sebagai tenaga kerja dalam rumah tangga dan sebagai tenaga kerja dalam usaha keluarga. Dalam peran ini wanita mempunyai pekerjaan yang sangat kompleks. Pekerjaan rumah tangga wanita dapat digolongkan pada kegiatan-kegiatan; menyiapkan makanan, mengasuh anak, membersihkan rumah, mencuci pakaian, mencuci perabot rumah tangga dan lainlain.

2. Peranan wanita sebagai pencari nafkah diluar usaha keluarga. Dalam peran ini wanita terdorong untuk bekerja mencari nafkah guna menambah pendapatan keluarga.

3. Peranan wanita pada pengambil keputusan rumah tangga. Dalam peran ini wanita dan pria dalam ikatan suami-istri, masingmasing mempunyai potensi untuk mempengaruhi pasangan dan potensi ini nampak dalam proses pengambilan keputusan dalam berbagai kegiatan yang mempengaruhi kehidupan keluarga. ${ }^{12}$

\section{Keluarga Miskin}

Miskin adalah tidak berharta benda atau serba kurang. Sementara menurut Soekanto dalam jurnal analisis sosial, kemiskinan merupakan suatu kondisi

12 Eva Fitria. 2019. Peran Aktif Wanita Dalam Peningkatan Pendapatan Rumah Tangga Miskin. Jurnal Ecobisma Vol 6 No 2 hlm 55 
ketidaksesuaian penghasilan untuk memenuhi kebutuhan dasar manusia yang terjadi secara terusmenerus dengan waktu relatif lama seiring dengan ritme kehidupan sehari-hari dan akan mempengaruhi tingkat konsumsi, kesehatan, dan proses pengambilan keputusan. Kemiskinan merupakan masalah sosial yang rumit. Kemiskinan tidak saja berkenaan dengan rendahnya pendapatan dan tingkat konsumsi masyarakat, tetapi juga berkaitan dengan rendahnya tingkat pendidikan dan kesehatan, ketidakberdayaan untuk berpartisipasi dalam proses pengambilan keputusan publik (powerlessness), ketidakmampuan menyampaikan aspirasi (voicelessness), dan rendahnya mutu hidup manusia (buman development). Keluarga "miskin" dapat dikategorikan menjadi tiga kelompok:

1. keluarga yang benar-benar miskin. Biasanya keluarga yang benar-benar miskin menerima apa adanya (tidak mempunyai posisi tawar), takut berhutang, mau bekerja keras, dan tidak mempermasalahkan keputusan publik. Kelompok ini perlu dilibatkan dalam sosialisai program, baik ekonomi (materi) maupun pendidikan politik, agar para elite lokal tidak mempermainkannya,

2. keluarga yang mampu tapi dianggap miskin. Kelompok ini biasanya lebih mementingkan individualisme. Terlebih bagi yang mempunyai akses publik, mereka akan memanfaatkannya demi keuntungan dirinya. Dalam hal ini bantuan tidak harus berwujud materi,

3. keluarga miskin tapi dianggap mampu. Kelompok ini mempunyai kehidupan yang setara dengan kelompok keluarga yang benar-benar miskin, karena resources (penghasilan) yang dinilai besar harus dibagi-bagi sehingga porsi yang diterimanya berkurang. Kekuasaan elite lokal harus mendapat perlawanan atau ada kontrol, agar program tepat sasaran. Akhirnya, penentuan kriteria miskin atau batasan kemiskinan haruslah mencakup berbagai aspek (luas dan menyeluruh) dengan memperhatikan standar penilaian yang khusus.Agar tidak terjadi kesenjangan yang semakin besar antara yang miskin dan kaya, peranan elite lokal yang objektif dan berpihak kepada rakyat miskin sangatlah diperlukan. ${ }^{13}$ (Handayani, 2009: 9) Dalam keluarga miskin perempuan single mother memiliki peran untuk kelangsungan hidup keluarga dan pekerjaan rumah tangganya. ${ }^{14}$

Dalam keluarga dimana perempuan sebagai orang tua tunggal menjalankan tuntunan untuk bekerja dan mampu menghadapi segala permasalahan dalam mempertahankan kelangsungan hidup keluarganya, mengharuskan seorang perempuan mencari nafkah untuk memenuhi kebutuhan sehari-hari setelah suami meninggal ataupun bercerai. Perempuan sebagai kepala keluarga yang secara finansial dan sosial di dukung oleh keberadaan suami, setelah adanya perpisahan, perceraian dan kematian maka perempuan akan bekerja sebagai tulang punggung keluarga.

Dalam masyarakat anggota keluarga merupakan suatu sumber daya yang harus dimanfaatkan untuk dapat bekerja, baik itu untuk menyelesaikan pekerjaaan rumah tangga maupun pekerjaan yang mempunyai potensi untuk menambah ekonomi atau pendapatan keluarga. Walaupun pekerjaan-pekerjaan yang hanya menghasilkan upah atau pendapatan yang rendah. Hal ini bagi keluarga miskin dianggap sebagai suatu yang sudah menguntungkan. Karena adanya anggapan ketimbang nganggur ono ngomah. Pada keluarga yang miskin biasanya pekerjaanpekerjaan domestik cenderung hanya terbatas

${ }^{13}$ Ninik Handayani. 2009. Menyimak Kebidupan Keluarga Miskin. Jurnal Analisis Sosial Vol 14 No 2 hlm 9

14 Ni Luh Arjani. 2002. Gender dan Permasalahannya. Pusat Studi Wanita Universitas Udayana 
pada memasak untuk keluarga dan mencuci pakaian serta membersihkan rumah, hal itu dapat dilakukan pagi hari atau bahkan anakanak mereka sudah dapat membantu untuk menyelesaikan pekerjaan domestik. ${ }^{15}$

Di dalam keluarga miskin yang para ibu rumah tangga single mother terpaksa harus menjadi pekerja di berbagai sektor untuk membantu perekenomian keluarga untuk memenuhi kebutuhan hidupnya, tentu saja sebagian besar dari waktunya dialokasikan di luar rumah untuk bekerja mencari nafkah. Dengan demikian, sisa waktu untuk aktivitas mengurus rumah, menjadi sedikit. Mereka terpaksa harus mengorbankan sebagian besar waktu yang seharusnya diperuntukan bagi urusan rumah tangga, karena sebagian besar waktu harus dicurahkan bagi pekerjaannya di luar rumah.

\section{Peran Perempuan Jorong Balai Mansiro dalam Keluarga}

Adapun mata pencaharian para kepala keluarga yang tergolong sebagai rumah tangga miskin tersebut adalah bermacam-macam. Ada sebagian yang bermata pencaharian sebagai nelayan tradisional, ada yang berprofesi sebagai petani, sebagai buruh kasar, sopir, tukang ojek dan berbagai profesi lain yang sering kali tidak tetap; disesuaikan dengan kondisi dan peluang yang ada. Keadaan mata pencaharian seperti yang digambarkan di atas, menyiratkan keadaan penghasilan yang sering kali tidak cukup untuk memenuhi kebutuhan dasar keluarga. Jika dilihat dari peran wanita dalam rumah tangga, maka dapat digolongkan:

\section{Peran Tradisional}

15 Iqbal, Muhammad. 2016. Peran Wanita Bekerja Dalam Meningkatkan Ekonomi Keluarga Miskin di Kota Jambi. Jurnal Ekonomi dan Sumber Daya Lingkungan Vol 5 No 2
Peran ini merupakan wanita harus mengerjakan semua pekerjaan rumah, dari membersihkan rumah, memasak, mencuci, mengasuh anak serta segala hal yang berkaitan dengan rumah tangga. Pekerjaanpekerjaan rumah tangga dalam mengatur rumah serta membimbing dan mengasuh anak tidak dapat diukur dengan nilai uang. Ibu merupakan figure yang paling menentukan dalam membentuk pribadi anak. Hal ini disebabkan karena anak sangat terikat terhadap ibunya sejak anak masih dalm kandungan.

2. Peran Transisi

Adalah peran wanita yang juga berperan atau terbiasa bekerja untuk mencari nafkah. Partisipasi tenaga kerja wanita atu ibu disebabkan karena beberapa factor, misalnya bidang pertanian, wanita dibutuhkan hanya untuk menambah tenaga yang ada, sedangkan di bidang industri peluang bagi wanita untuk bekerja sebagai buruh industry, khususnya industry kecil yang cocok bagi wanita yang berpendidikan rendah. Faktor lain adalah masalah ekonomi yang mendorong lebih banyak wanita untuk mencari nafkah.

3. Peran kontemporer

Adalah peran dimana seorang wanita hanya memiliki peran di luar rumah tangga atau sebagai wanita karier. Wanita dengan peran kontemporer ini banyak menghabiskan waktunya di luar rumah tangga dan banyak menghabiskan waktunya untuk meningkatkan jenjang karirnya.

Perkembangan zaman yang semakin canggih menyebabkan tidak sedikit wanita yang memasuki sektor publik, untuk bekerja di berbagai sektor kehidupan. Masuknya wanita dalam sektor publik tersebut menyebabkan bertambahnya peran yang harus dilaksanakan. Selain berperan dalam sektor domestik yang sebagai ibu rumah tangga yang mengurus rumah tangga dan anak-anak, wanita juga 
berperan dalam sektor publik sebagai pencari nafkah dalam keluarga. ${ }^{16}$

McClleland mengatakan, sebenarnya untuk memotivasi seseorang atau kelompok orang bisa dilakukan dengan mengubah khayalan orang melalui cerita-cerita dan kepiawaian seseorang yang bisa mempengaruhi sehingga nilai-nilai perubahan muncul dalam hidupnya, ia teransang untuk mengikuti dan keluar dari permasalahannya hidupnya. ${ }^{17}$ Kondisi kemiskinan mendorong perempuan untuk ikut mengambil ailh tanggung jawab ekonomi keluarga. Dengan berbagai cara perempuan ikut berperan aktif menaikkan pendapatan. Perempuan miskin di desa dan kota merupakan kelompok terbesar yang terus-menerus mencari peluang kerja demi memenuhi kebutuhan dasar. Mereka bekerja sebagai buruh tani, buruh perkebunan, pembantu rumah tangga, pemulung, buruh pabrik, dan pekerja migran. Sementara proses pembangunan telah merugikan kaum perempuan. Mereka menjadi miskin dan temarginal. Pesatnya pembangunan menyebabkan tersingkirnya tenaga kerja perempuan ke sektor-sektor marginal karena perempuan tidak mempunyai pengetahuan dan ketrampilan yang cukup memadai seiring dengan laju pembangunan.

\section{Kesimpulan}

Tugas perempuan menjadi lebih berat jika menjadi orang tua tunggal (single mother). Setiap perempuan yang sudah menikah pastilah tidak pernah berharap menjadi seorang single mother, keluarga lengkap tetap menjadi idaman setiap perempuan, namun

16 Indaryani Mamik. 1997. Peran Wanita dalam Menunjang Ekonomi dalam Rumah Tangga Miskin: Studi Kasus di Kecamatan Selogiri Kabupaten Wonogiri Jawa Tengah. Warta Demografi Th 27. No. 4.

17 Elvita, Y., Hanani, S., \& Helfi, H. 2018. Pemberdayaan Masyarakat Muslim Kepulauan Dengan Penguatan Achievement Mativation Untuk Mengatasi Perilaku Hedonisme Dalam Masyarakat Dendun Kecamatan Mantang Kepulauan Bintan. Humanisma: Journal of Gender Studies, 2(1). adakalanya nasib berkehendak lain. single mother menjadikan perempuan sebagai kepala kelurga, dimana perempuan memiliki peran ganda bagi ibu yaitu sebagai orang tua tunggal untuk mengurus anak-anaknya dan ia juga dituntut untuk bekerja guna mencari nafkah untuk memenuhi kebutuhan keluarganya. kemiskinan merupakan suatu kondisi ketidaksesuaian penghasilan untuk memenuhi kebutuhan dasar manusia yang terjadi secara terusmenerus dengan waktu relatif lama seiring dengan ritme kehidupan sehari-hari dan akan mempengaruhi tingkat konsumsi, kesehatan, dan proses pengambilan keputusan. Kemiskinan merupakan masalah sosial yang rumit. Kemiskinan tidak saja berkenaan dengan rendahnya pendapatan dan tingkat konsumsi masyarakat, tetapi juga berkaitan dengan rendahnya tingkat pendidikan dan kesehatan, ketidakberdayaan untuk berpartisipasi dalam proses pengambilan keputusan publik (powerlessness), ketidakmampuan menyampaikan aspirasi (voicelessness), dan rendahnya mutu hidup manusia (buman development).

\section{Daftar Pustaka}

Arjani, Ni Luh. 2002. Gender dan Permasalahannya. Pusat Studi Wanita Universitas Udayana

Elvita, Y., Hanani, S., \& Helfi, H. 2018. Pemberdayaan Masyarakat Muslim Kepulauan Dengan Penguatan Achievement Mativation Untuk Mengatasi Perilaku Hedonisme Dalam Masyarakat Dendun Kecamatan Mantang Kepulauan Bintan. Humanisma: Journal of Gender Studies, 2(1).

Maripadang, Sarnita. 2013. Peran Single Parent Dalam Menjalankan Fungsi Keluarga. Skripsi: Universitas Hasanuddin

Musyiroh, Nilatul. 2018. Peranan Perempuan Single Parent Dalam Peningkatan Kesejabteraan Keluarga. Skripsi. Universitas Islam Negeri Sumatera Utara. Hlm 9

Fadillah, Nur. 2015. Peran Ibu 'Single Parent" Dalam Menumbubkan Kemandirian Anak 
Di Desa Bojong Timur Magelang. Skripsi. Fakultas Ilmu Sosial Universitas Negeri Semarang

Fitria, Eva. 2019. Peran Aktif Wanita Dalam Peningkatan Pendapatan Rumah Tangga Miskin. Jurnal Ecobisma Vol 6 No 2

Cahyani, Kurnia Dwi. 2016. Masalab Dan Kebutuban Orang Tua Tunggal Sebagai Kepala Keluarga. E-Journal Bimbingan Konseling Edisi 8 tahun ke-5

Hanani, Silfia. 2013. Tanah Ulayat dan Kemiskinan Perempuan. Jurnal Qafa'ah. Vol 3 No 1

Hanani, Silfia. 2018. Woman's Newspapers As Minangkabau Feminist Movement Againts Marginalization In Indonesia. Jurnal GJAT. Vol 8 No 2

Handayani, Ninik. 2009. Menyimak Kebidupan Keluarga Miskin. Jurnal Analisis Sosial Vol 14 No 2

Indaryani, Mamik. 1997. Peran Wanita dalam Menunjang Ekonomi dalam Rumah Tangga Miskin: Studi Kasus di Kecamatan Selogiri Kabupaten Wonogiri Jawa Tengah. Warta Demografi Th 27. No. 4.

Henslin, James M. 2007. Sosiologi dengan Pendekatan Membumi. Jakarta: PT Gelora Aksara Pratama

Iqbal, Muhammad. 2016. Peran Wanita Bekerja Dalam Meningkatkan Ekonomi Keluarga Miskin di Kota Jambi. Jurnal Ekonomi dan Sumber Daya Lingkungan Vol 5 No 2

Rahayu, Afina Septi, 2017. Kebidupan Sosial Ekonomi Single Mother dalam Ranah Domestik dan Publik. Jurnal Analisa Sosiologi Vol 6 No 1

Ritzer, George. 2014. Teori Sosiologi Modern. Jakarta: Pranadamedia Group

Utami, Nofrianti dan Silfia Hanani. 2018. Kebertahanan Perempuan Simalanggang Menjadi Single Mother. Jurnal Turast Vol 6 No 1 